\title{
THE STATE MEASURES HOW TO IMPROVE THE USE AND PROTECTION OF LAND PLANTED BY PROTECTIVE FOREST BELT
}

\author{
Valentyna BOKLAG ${ }^{1}$ \\ Classic Private University, Ukraine
}

\begin{abstract}
A problem of protective forest belt control expends because with the General deterioration of the existing forest belt is considered this article; a number of measures for the transfering of land plandet by protective forest belt to municipal authority, are suggested village councils. Methodology. The study is based on the analysis of modern legislation, which regulates the use of the territories occupied by forest belts. We used statistical data, as well as the work of scientists who have examined the current state, the rational use and the question of the protection land for shelterbelts. The research results showed that at the moment there is no clear (correct) information, which is true for the use of forest plantations, their quantitative and qualitative characteristics. There is a need for reconstruction of the existing and creation of new belts to improve their protective function for the productive land. The practical importance. The results are scientifically substantiating the improvement of the legislative framework to regulate the use of forest windbreaks, as well as the need to transfer the shelterbelts from the state to the municipal property. Value/originality. These results provide justification for the adoption of the «Transferring Program of forest belts from the state to municipal ownership of rural and urban councils».
\end{abstract}

Key words: protective afforestation, use and protection of lands, local authorities, municipal land property, land resources.

\section{JEL Classification: Q15, Q23, Q24, R14}

\section{Statement of the problem}

One of the main problems of land use planted by field protection forest belt in Ukraine and other nonagricultural land, was the legal uncertainty of it's property right fate during land reforms and it's land division of collective agricultural enterprises. The importance of the problem increases because legal aspects of land use, planted by protective forest belt, techniques of effective of these territory effective control have not sufficiently studied.

According to the Land Code of Ukraine field protective forest belt and other protective plantations are classified as non-agricultural land for agricultural purposes. These objects should be owned by village councils. However, the mechanism of such land use is not provided in the current legislation, which means that local governments, as owners, can not manage this property. Consequently, it is controlled illegally by other people, who cut down and damage forest belt.

State protective forest belt transfer under municipal control as their property is a real way of this problem solution concerning field protective forest belt and other protective plantation future viability.

Corresponding author:

${ }^{1}$ Department of Public Administration and Land Management

E-mail:val.boklag@yandex.ru

\section{The legal regime of the use protective belts}

The development of urbanization processes and the growth of world population causes an increase in the material needs of society and the inability of the biosphere in its entirety to ensure their demands causes the intensive using of land and forest resources. In view of the increasing human pressure on land and forest resources, high rate of land plowed, the excessive using of chemicals soil, development of erosion processes, reduced land productivity, development of arable and forest land for construction, mass uncontrolled deforestation issues of rational and ecological using of land and forest resources are extremely important and actual as in a scientific point of view (Hordienko, 2010).

According to cl. 60 of the Law of Ukraine «About the Environmental Protection» shelterbelts natural band is a type of natural areas and a subject to special state protection. However, this law does not contain the definition of these natural areas, as well as their legal regime. Though the natural belts usually represented as areas covered with forests, and the relations in it are mainly regulated by the forest legislation. Thus, cl. 36 of the Forest Code, which regulates the division of forests into groups and to classify 
them in categories of protection of environmental and economic importance include windbreak to the first group of forests like those that operate primarily environmental functions.

The definition of this category of special protection areas is provided the Procedure of division the forests into groups, their reference to the categories of protection and allocation of specially protected land forest fund, approved by the Cabinet of Ministers of Ukraine dated July 27, 1995. Belts (windbreak) is artificially created line-type plantings to protect agricultural land (p. 24 of the Procedure). These forests are classified as protective forests (next to water protection, hygiene, health and certain other categories of protection, forming forests of the first group). Thus, according to p.3 of the Procedure the belts in other categories of protection are not defined. Field shelters make primarily protective, anti-erosion, climate-and other useful functions. The legal regulation of windbreak is not written in detail. It does not set the standards of the sizes of these bands. Some requirements are contained in legislation only in part of the limit the logging of this category (Cabinet's of Ministers of Ukraine Resolution, 2014).

Hodovanyuk A. J. analyses the current legislative regulating relations associated with the use and protection of belts (Hodovanyuk, 2012). He highlighted the main historical stages of their creation and operation in Ukraine, formulated the problems caused by the transfer of the ownership and lease of agricultural land, namely the absence of the owner of belts and other plantations became a critical issue of national importance; lack of reliable information about their actual state; the belts were left to fend for themselves after the carve-up and reorganization of collective agricultural enterprises; forestry enterprises strongly against the ideas to transfer belts on their balance, noting that holding inventory, care, work on their reproduction require significant material costs. The solution of these problems, according to him, needs the following legislative changes: p. 22 of the Land Code of Ukraine, where it is said about agricultural land, in paragraph 2-b belts should be deleted from the list of non-agricultural land for the purpose of classifying these and other protective plants to the land for forestry for determining the uncertainty status of the land planted with forest belt plantings.

\section{The current state of protective belts}

In Ukraine, there are nearly 450 thousand hectares occupied by belts, but recently very aggravated the problem of their preservation and reproduction. Such land is classified as agricultural land and is used to form the environmentally safe agricultural landscapes, land management, land use adjacent agroforestry protection from negative degradation processes (water, wind erosion).

The problem with retaining of shelterbelts deepens in connection with the general deterioration of the existing forest belts, restricted funds for their maintenance. Therefore there is a need to establish a host of territories occupied shelterbelt forest plantations in order to determine measures for their rational use and protection. In our opinion, today it is not enough to create new shelterbelts to achieve abstract optimum performance, but also to draw attention to the preservation and improvement of the condition of forests and protective plantations, inherited by the present generation as an inheritance. Now the work of the forest fund accounting is the inefficient, since the area and forest cover differ, according to the executive body on the issues of land use, State Forestry, the State Service statistics. In fact, at the moment we do not have information about the actual forest area in the country and its forest cover. Before the land reform (1991) work on the creation and maintenance of shelterbelt plantings were in management of the local farms as usual. The bulk of the plantations were founded in 50-60s of the last century due to the «Stalin's Plan for the Transformation of Nature» (1948). This document provides for the formation during 1950-1965's state forest shelterbelts with total length of $5320 \mathrm{~km}$ and an area of forest plantations 117.9 thousand ha (Kindyuk, 2011).

In the process of transformation of land ownership in 90 years a number of changes was held, namely, 28 million hectares of agricultural land passed into private ownership to 7 million shareholders, the land under the shelterbelt forest plantations transferred to the collective 37 agricultural enterprises formed on the basis of former collective farms and state farms. Since windbreak and other shelterbelts planting apply to non-agricultural land, they were relegated to the lands, which are not subject of unitization and in the future could be a part of the stock lands of the reserve fund, the public, or, and still be in the collectively owned (Yuhnovskiy, 2009).

Analysing the materials of the Conference of the United Nations as for Problems of Environment and Development (2012), the Ministerial Conference on the Protection of Forests in Europe (2011), the thesis of the Forest Code of Ukraine (Forest Code of Ukraine), the Cabinet of Ministers of Ukraine «On Approval of the Concept of Development of Agro-forestry in Ukraine «dated September 18, 2013 (Popkov, 2011), it should be noted that the management of land and forest resources is an important condition for the creation of environmentally sustainable conditions of nature, which are also relevant for the agricultural regions of Ukraine. At the same time one of the main organizational and legal issues of land use of the shelterbelt plantings is to define the forms of ownership to them, due to the transformation process of ownership of the land, which occurred during the land reform.

In order to ensure the implementation of urgent measures to accelerate land reform, according to the Decree of the President of Ukraine $\ll$ On the order of unitization land transferred into collective ownership of agricultural enterprises and organizations 》 № 720 from August 081995 in the sphere of agricultural production 
the farmland which was the subject of unitization was transferred to collective ownership, agricultural enterprises, cooperatives, joint stock companies, including those, that were created on the basis of state farms and other state agricultural enterprises. That is, the document led to the elimination of and reorganization of the majority of collective farms. At the same time, the process of the carve-up of non-agricultural land, including land for shelterbelt plantings, were not included.

Now there were practical cases that could be in the course of the transformation of collective ownership in the legislative sphere of non-agricultural land, and especial land for belt plantings. Consequently, the determination of their legal status is still the current organizational and legal issue, on which depends the rational use of land under the shelterbelt plantings.

\section{Rationale for further use shelterbelt plantings}

Based on the principles of social and economic policy in the short term, within the framework of public administration of decentralization measures, including land, urgent action must be considered in order to achieve optimal indicators in agricultural production, preservation and improvement of protective plantations, inherited by the present generation as an inheritance. This problem requires a complex solution, which is possible through the use of target program method, ensuring the introduction of advanced technologies, and through a systematic approach to the ecological and economic feasibility of the system shelterbelts, harmonizing their output and requirements for the implementation of agroforestry protection adjacent land uses from negative degradation processes.

Y. V. Onika gives the most actual issue of the legal status of land on which the forest plants of agroforestry are located. The scientist said that today the status of belts and their owner are not identified; there is the problem of the actual provision of agriculture land in permanent use of state and municipal enterprises (Onika, 2012).

M. Popkov analysed several options regarding the maintenance of land for windbreaks, belts and agriculture care of:

- The state is interested in the proper accounting, security, maintenance and increasing the area of belts;

- Owners and tenants of agricultural land usually do not have land for belts consisting of tenure and don't have to bear the costs of their maintenance;

- State forest departments, enterprises are not interested to take the land under the balance of belts in permanent use, because creation and care for them unprofitable and require significant funding;

- In terms of lack of funds rural and regional councils do not want to spend local budgets for the maintenance of belts and do not do it, referring to the fact that the windbreak is located outside of the localities and can not be attributed to municipal property (Popkov, 2011).
Taking into account all the views of each subject which uses the belts as well as their positive impact, it is important to consider while developing the transmission mechanism of land in rental and encourage land users in the creation of new belts and maintenance of existing ones.

It should also be underscored that the restoration of agronomy structure, which could lead the proper care of the land for belts, is not provided in law. The absence of the owner, which could protect and control the state of these plantations, due to extensive logging, irrational use, placing of natural landfill, could create a national environmental problem in a very short term.

Large agricultural companies, of course, can ensure the protection of land for belts but all the major agricultural producers work on leased land and the absence of safeguards to renew the lease or purchase of land they do not hurry to make large long-term investments in forestry. Moreover, no certainty of further strategy for land reform along with plans to limit the legal arable land in one manufacturer does not allow for strategic planning of land use. Furthermore, most of the owners and users of arable land belong to small land users who can not afford create plantations shelter individually, take care of them. They could plant protective plantings on their small plots, but we can hardly expect that such landings will be functional in agroforestry systems.

In addition, the legislation Ukraine, unlike the EU, does not provide economic incentives for private landowners who provide shelter forest plantations on their lands. If the situation does not change, we do not have to expect that the resources of the landowners who own much of the arable land will be used for forestry.

Thus, the main problem in using land for belts is that they actually exist as an independent property and at the same time separated from agricultural land, which they must defend, providing their main function of agroforestry. As a result, there was a gap of Economic Relations: agroforestry rents which is generated in agricultural land use does not support these plantations, due to the positive impact of land for planting shelterbelts, and, conversely, land under plantations shelter left by themselves, form a negative rent if it is viewed only as a woody resources (industrial wood, firewood).

\section{Recommendations for the efficient use of forest plantations.}

In our opinion, the solution to the continuing effectiveness of afforestation, restoration of their network in order to improve their protective function for productive lands, it is necessary to transfer them into the ownership of local communities, that is in the municipal property. We offer to solve problems related to the transfer of land from the state and the collective to the municipal property of local communities in rural village councils, through:

- Determination by transmitting the status of belts through the transferring it in communal ownership of 
village councils for appropriate accounting, security, maintenance and increase the area of shelterbelts;

- The establishment of the owner to the territories occupied forest belt plantations in order to determine measures for their rational use and protection;

- The use of an effective system of qualitative and quantitative accounting and valuation of land for belts for the organization of rational use and protection;

- Carrying out a complete inventory of land occupied by windbreaks in the region;

- Demarcation of territories occupied by belts and determination their sizes and areas;

- Implementation of mapping the territories occupied by belts and village councils;

- A survey of the state of shelterbelts, the adjustment of the materials of previous surveys;

- Prevention of degrading processes of soil, in particular on agricultural land, through the creation of protective forests as an effective means and inherent mechanism of protection and optimization of agricultural ecosystems.

Despite the imperfection of the legal framework aimed on regulating the future use of the land occupied by shelterbelts, we consider that it is necessary to take on a regional level «The Program of transmission the forest belt from the state and municipal property to the collective property of village territories councils».

The main aim of which should be:

- Ensure the efficient use of land resources, creating optimal conditions for a significant increasing in the production potential of land, the growth of its economic value;

- Maximize the ecological and economic effects of belt plantings as an active regulator of ecological and biological balance;

- Creating a unique farmland forest agricultural landscape, which will expand the species composition of flora and fauna, and is a factor in the preservation and enrichment of natural soil components, performs sanitaryhygienic, esthetical, recreational, and other functions.

- The formation of agricultural landscapes management frameworks using agroforestry techniques and the creation of an optimized network agro systems belt plantings.

We consider that the program should include the following measures in the transferring belts to the property: - The development of land use documentation and feasibility studies for transferring of land from the state and the collective to the municipal property;

- Improving the system of self-control over the use and protection of lands occupied by field protection areas;

- Conducting scientific justification reconstruction of the existing network of shelterbelt plantings and design of new belts in order to protect the surrounding land uses agroforestry from negative degradation processes.

The result of such a program should be a transferring of belts from the state to the municipal property and increasing the efficiency of their use and protection. Windbreak plantings are an integral part of a system of measures aimed at increasing the cropping intensity; it is increasing agricultural productivity while reducing its cost.

\section{Conclusions}

In our view, to ensure the effective use of land occupied by belts it is needed to determine their legal and transferring the territory to the ownership of territorial communities. The implementation of complex measures on the transferring of land occupied by belts in the municipal property will create an effective mechanism for the preservation and improvement of protective forests.

\section{References}

Hodovanyuk A. Y. (2012). Forest Belts for More than Twenty Years in need of Protection. The Legal Aspect of the Problem. Collection of papers of Actual Problems in Politics, issue 49, p. 228-327.

Hordienko V. P. (2010). Ecological and economic efficiency of using agricultural land. Abstract of PhD dissertation. Econ. Science. "Economics of natural resource management and protection environment". Sumy,. $21 \mathrm{p}$.

KindyukB. V. (2011). Organizational and Legal Basis for Implementation of « Stalin's Plan of Nature Transformation $\ll 1948$ as for Creating Growing New Forests in the USSR. Science Journal of National University of Life and Environmental Sciences of Ukraine, issue 165, part 2, p. 24-32.

Forest Code of Ukraine from 21.01.1994 № 3852-XII The Verkhovna Rada of Ukraine, № 17, p. 99.

Onika Y. V., (2012) Some Problems of Practical Use and Protection of Agroforestry in Ukraine. Journal "Lawyer in Ukraine ", issue № 4, p. 91-96.

Openko I. A., Yevsiukov T.O., (2014), Dales for Shelter: Modern State, Problems, Ways of Solving. Journal of Sustainable Natural Resource Management, № 1, p. 125-131.

Popkov M., (2011) Afforestation in Ukraine : facts and illusions, Electronic source: http://proeco.visti.net/lib/ lesorazvedenie na ukraine.pdf.

Cabinet's of Ministers of Ukraine Resolution , (2014), "Action Plan about Development of the Concept of Agroforestry in Ukraine” № 582 of 18 June 2014, Electronic source: http://www.kmu.gov.ua/control/uk/publish/ article? art id=247411603\&cat id=244274160.

Yuhnovskiy V. Yu., (2009), Solutions to Problems of Belts Afforestation in Ukraine, Scientific Works of Forestry Academy of Sciences of Ukraine, issue 7, p. 62-65. 


\section{Валентина БОКЛАГ}

\section{ГОСУДАРСТВЕННЫЕ МЕРЫ ПО СОВЕРШЕНСТВОВАНИЮ ИСПОЛЬЗОВАНИЯ И ОХРАНЫ} ЗЕМЕЛЬ, ЗАНЯТЫХ ПОЛЕЗАЩИТНЫМИ ЛЕСНЫМИ НАСАЖДЕНИЯМИ

Аннотация. В статье рассмотрена проблема по содержанию полезащитных лесонасаждений, которая углубляется в связи с общим ухудшением состояния существующих лесополос; предложен комплекс мероприятий по передаче земель занятых полезащитными лесонасаждениями в коммунальную собственность сельских, поселковых советов. Методика. Исследование основано на анализе современного законодательства, которое регулирует использование территорий занятых защитными лесонасаждениями. Использовались статистические данные, а также труды ученных, которые исследовали современное состояние, рациональное использование, а также вопросы охраны земель под лесонасаждениями. Результаты исследования показали, что в данный момент отсутствует четкая (правильная) информация, которая соответствует действительности по использованию лесонасаждений, их количественной и качественной характеристики. Возникла необходимость реконструкции существующих лесонасаждений и создание новых с целью повышения их защитной функции для продуктивных земель. Практическое значение. Полученные результаты научно обосновывают усовершенствование законодательной базы по регулированию использования лесозащитных насаждений, а также необходимость передачи полезащитных лесонасаждений из государственной в коммунальную собственность.Значение/оригинальность. Полученные результаты дают обоснование принятия «Программы по передаче полезащитных лесных насаждений из государственной в коммунальную собственность сельских и городских советов». 